\title{
PERAN ORANG TUA DAN PENDIDIK DALAM MENERAPKAN PERILAKU DISIPLIN TERHADAP ANAK USIA DINI
}

\section{THE ROLES OF PARENTS AND EDUCATORS IN THE APPLICATION OF THE DISCIPLINE BEHAVIOR OF EARLY AGED CHILDREN}

\author{
Ernie Martsiswati, Yoyon Suryono \\ Pendidikan Luar Sekolah PPs UNY, Universitas Negeri Yogyakarta \\ suryamarta@yahoo.com, yoyonsuryono@yahoo.com
}

\begin{abstract}
Abstrak
Penelitian ini bertujuan untuk mengungkapkan adanya hubungan peran orang tua dan pendidik dalam menerapkan perilaku disiplin terhadap anak usia dini. Menggunakan metode penelitian kuantitatif. Pengumpulan data dengan wawancara terstruktur skala Guttman, observasi dengan dokumentasi pada 35 anak usia dini di Kelompok Bermain Surya Marta Yogyakarta. Hasil penelitian adalah tingkat keeratan hubungan antara peran orang tua dengan perilaku disiplin anak usia dini adalah sangat lemah dan hubungannya berbanding terbalik, tingkat keeratan hubungan antara peran pendidik terhadap perilaku disiplin anak adalah lemah, dan hubungannya searah, tingkat keeratan antara hubungan peran orang tua dan pendidik secara bersama-sama adalah lemah dan hubungannya tidak searah. Rekomendasi hasil penelitian kepada orang tua dan pendidik supaya mengoptimalkan perannya dengan memberikan arahan kepada anak usia dini dalam berperilaku disiplin, mengadakan hubungan dengan bekerja sama dalam menerapkan perilaku disiplin terhadap anak usia dini.
\end{abstract}

Kata Kunci: peran orang tua dan pendidik, perilaku disiplin, anak usia dini.

\begin{abstract}
This study aims to investigate the relationship of parents and educators' roles in the application of the discipline behavior in early aged children The study employed the quantitative research method. The data collecting techniques included structured interviews using the Guttman scale and observations with documentation on 35 early aged children in Surya Marta Play Group Yogyakarta. The results of the study are as follows. The level of the relationship strength between parents' roles and the discipline behavior of early aged children is very low and the relationship of the two variables is negative. The level of the relationship strength between educators' roles and the discipline behavior of early aged children is low and the relationship of the two variables is positive. The level of the relationship strength of parentsand educators' roles as an aggregate is low and the relationship is negative. The recommendations from the results of the study are as follows: parents and educators should optimize their roles by giving guidance on the discipline behavior to early aged children. Parents and educators are expected to establish cooperative relationship in the application of the discipline behavior of early aged children.
\end{abstract}

Keywords: the roles parents and educators, dicipline behavior, early aged children. 


\section{PENDAHULUAN}

Pendidikan Anak Usia Dini (PAUD) me nurut UU Sisdiknas nomor 20 Pasal I ayat 14 tahun 2003 adalah suatu upaya pembinaan yang ditujukan kepada anak sejak lahir sampai dengan usia enam tahun yang dilakukan melalui rangsangan pendidikan untuk membantu pertumbuhan dan perkembangan jasmani dan rohani agar anak memiliki kesiapan dalam memasuki pendidikan lebih lanjut.

Melalui PAUD anak diharapkan dapat mengembangkan segenap potensi yang dimilikinya antara lain agama, kognitif, sosial-emosional, bahasa, motorik kasar dan halus, serta kemandirian, memiliki dasardasar aqidah yang lurus sesuai dengan ajaran agama yang dianutnya, memiliki kebiasaan-kebiasaan perilaku yang diharapkan, menguasai sejumlah pengetahuan dan keterampilan dasar sesuai dengan kebutuhan dan tingkat perkembangannya serta memiliki motivasi dan sikap belajar yang positif.

Masa usia dini anak adalah masa keemasan (golden age), Para ahli berpendapat bahwa masa usia dini, yaitu o - 6 tahun merupakan masa yang peka sekaligus masa kritis dari seluruh siklus kehidupan manusia. Pada masa ini anak mengalami perkembangan dalam diri mereka secara fisik maupun mentalnya, sehingga upaya pengembangan seluruh potensi anak usia dini harus dimulai agar pertumbuhan dan perkembangannya dapat tercapai secara optimal dengan meletakkan dasar-dasar pembangunan kemampuan fisik, bahasa, sosio-emosional, konsep diri, seni, moral dan nilainilai agama. Salah satu dasar pengembangan moral yang harus ditanamkan dalam diri anak sejak usia dini adalah disiplin.

Disiplin merupakan suatu ketaatan dan kepatuhan terhadap sesuatu yang telah disepakati, sehingga disiplin menjadi penting diajarkan pada anak usia dini supaya dapat belajar berperilaku dengan cara yang diterima oleh masyarakat dan oleh anggota kelompok sosial mereka. Tujuan disiplin bagi anak usia dini terbagi atas tujuan jangka pendek dan jangka panjang, adapun tujuan jangka pendek adalah membuat anak usia dini terlatih dan terkontrol, dengan meng- ajarkan bentuk perilaku yang pantas dan tidak pantas sedangkan tujuan jangka panjang adalah membentuk perkembangan pengendalian diri.

Pokok utama disiplin adalah peraturan. Peraturan adalah pola tertentu yang ditetapkan untuk mengatur perilaku seseorang. Peraturan yang efektif untuk anak usia dini adalah peraturan yang dimengerti, diingat dan diterima. Pola tertentu yang ditetapkan untuk mengatur perilaku anak usia dini dalam proses pembelajaran dilakukan pembiasaan perilaku. Perilaku pada saat berdoa memulai belajar, sebelum makan, mengucap salam pada guru dan teman, mencuci tangan sebelum makan, merapikan mainan setelah bermain, berbaris sebelum masuk ruangan kelas dan sebagainya, perilaku ini hendaknya dilakukan secara konsisten.

Tim Diklat Dasar Himpaudi Provinsi DIY (2012, Juli), Maria Montessori (18701952) mengatakan pentingnya lingkungan yang bebas dan penuh kasih agar potensi yang dimiliki anak dapat berkembang secara optimal. Lingkungan pendidikan yang pertama dan utama bagi anak usia dini adalah lingkungan keluarga yaitu orangtua. Semua bentuk pengajaran dari orang tua akan berfungsi mengoptimalkan perkembangan anak baik dalam aspek fisik, kognitif dan emosi. Selain itu, orang tua yang memberikan stimulasi optimal akan membuat anak menjadi cerdas, termasuk dalam memecahkan masalah. Stimulasi yang tepat juga mampu membuat hubungan antara orang tua dan anak menjadi lebih hangat dan lebih bahagia sehingga anak cenderung lebih mudah diatur.

Lingkungan pendidikan kedua bagi anak usia dini adalah lingkungan lembaga PAUD, yang disamakan dengan lingkungan sekolah. Sekolah untuk anak usia dini sebenarnya berfungsi untuk menguatkan karena sekolah adalah rumah kedua bagi anak. Selain itu tempat pertemuan berbagai karakter dan berbagai macam pola asuh. Jika dari lingkungan rumah sudah kuat, maka sekolah hanya tinggal melanjutkan, dengan demikian akan menghasilkan anak-anak yang diharapkan orang tua. Peran guru di sekolah sebagai formalitas, membantu anak- 
anak mengembangkan kompetensi dan potensi anak secara luas, menambahkan dasar-dasar profesional, meneropong aspek akademik lainnya.

Kunarwoko \& Juliana (2012, September), dalam Seminar Anak Usia Dini TK Tarakanita 5 - Jakarta, Ada fakta anak Indonesia bahwa ternyata memiliki "play quotion" (tingkat bermain) paling rendah dibandingkan dengan anak-anak dari negara lain seperti Jepang, Thailand dan Vietnam, sebuah penelitian menunjukkan, anak Indonesia menghabiskan sebagian besar waktu mereka untuk belajar dan kegiatan non fisik ,misalnya menonton TV dan bermain game, banyak orang tua tidak menyadari anaknya marah atau sedih dan cenderung tidak peduli, padahal anak ketika itu butuh perhatian. Akibatnya banyak anak akan tumbuh jadi tertutup dan tidak bisa mengelola emosinya dengan stabil, sebagian besar orang tua tidak menyadari bahwa usia nol sampai lima tahun, adalah usia sangat penting, karena pada periode itulah masa emas pembentukan otak dan kepribadian anak terjadi, banyak orang tua tidak intensif melakukan Pendidikan Anak Usia Dini (PAUD) pada masa emas pembentukan otak ("Golden Age") itu, banyak anak, hidup dan berkembang dari orang tua yang bekerja. Di kota besar, karena tuntutan hidup, suami dan isteri bekerja adalah hal yang wajar. Akibatnya anak tidak cukup waktu untuk bertemu, berbicara dan berkomunikasi dengan orang tuanya, sebagian besar anak di Indonesia, menghabiskan waktunya diluar rumah, baik di sekolah, maupun lingkungan teman-temannya. Dampak pergaulan di luar rumah yang baik maupun buruk tidak selalu bisa dikontrol dan disadari orang tua, gadget dan teknologi informasi, menyerbu anak-anak kita. Dampaknya yang kurang baik, tidak selalu bisa diatasi orang tua, khususnya anak yang tinggal di kota besar menjadi semakin "egois" karena terkurung di rumah atau apartemen yang kurang "gaul" dengan anak-anak lain. "Nostalgia" orang tua yang tinggal di kampung, masih bisa main kasti, memandikan kerbau di sawah, gobag sodor bersama teman-teman di malam bulan purnama, tinggal kenangan masa lalu, sebagian besar anak, khususnya di perkotaan lebih banyak menghabiskan waktunya di depan TV, game, handphone. Mereka juga lebih banyak menghabiskan waktu bersama teman atau pembantu, bukan bersama orang tua.

Dari beberapa fakta yang ada didapat bahwa masih banyak orang tua belum menerapkan pola tertentu yang dipakai dalam mengasuh anak. Pola tertentu yang dilakukan dalam mendidik anak dan menjaga anak secara terus menerus dari waktu ke waktu sebagai perwujudan rasa tanggung jawab orang tua terhadap anak adalah Pola Asuh. Melalui pola asuh yang baik, anak akan diarahkan bagaimana membiasakan diri melakukan hal-hal secara teratur dan terjadwal. Agar orang tua dan pendidik dapat berperan menerapkan pola asuh yang baik perlu dibekali dengan pengetahuan dan keterampilan serta pembinaan tentang pentingnya PAUD, kesadaran orang tua dalam menerapkan disiplin.

Mengingat anak merupakan amanah dan karunia Tuhan Yang Maha Esa, yang dalam dirinya melekat harkat dan martabat sebagai manusia seutuhnya. Anak adalah tunas, potensi dan generasi muda penerus cita-cita perjuangan bangsa Indonesia. Untuk membangun bangsa yang maju diperlukan anak usia dini yang berperilaku disiplin, karena masa depan bangsa Indonesia ditentukan oleh pendidikan yang diberikan kepada anak usia dini yang sekarang ini. Oleh karena itu orang tua dan pendidik dituntut untuk serius memperhatikan pendidikan anak usia dini pada setiap tahap perkembangan. Karena kedisiplinan merupakan hal yang sangat penting untuk diterapkan sejak dini melalui pola asuh yang baik dan benar, maka penelitian ini dilakukan untuk mengetahui bagaimana peran orang tua dan pendidik dalam menerapkan perilaku disiplin terhadap anak usia dini.

Penelitian ini bertujuan untuk memperoleh data empiris mengenai (1) Pengaruh peran orang tua dan pendidik dalam menerapkan perilaku disiplin terhadap anak usia dini, (2) Pengaruh peran orang tua dalam menerapkan perilaku disiplin terhadap anak usia dini, (3) Pengaruh peran pendidik dalam menerapkan perilaku disiplin terhadap anak usia dini. 
Penelitian ini diharapkan dapat berguna secara teoritis memberikan kontribusi positif terhadap teori, minimal penguatan faktor-faktor yang mempengaruhi perilaku disiplin anak usia dini. Secara Praktis orang tua bisa menerapkan perilaku disiplin dalam kehidupan sehari-hari di rumah dalam rangka membantu perkembangan moral anak usia dini, Pendidik bisa menerapkan perilaku disiplin di lingkungan lembaga PAUD dalam rangka membantu perkem-bangan moral anak usia dini, memberikan kesadaran bagi masyarakat betapa pentingnya menerapkan kedisiplinan serta menciptakan generasi muda yang memiliki akhlak yang mulia, peneliti mendapat wawasan, pengalaman dan referensi tentang menerapkan perilaku disiplin anak usia dini, hasil penelitian ini diharapkan dapat memberikan sumbangan pemikiran bagi penelitian selanjutnya dan dimanfaatkan oleh pihak-pihak terkait dalam pendidikan dan dalam peningkatan kedisiplinan anak usia dini di Lembaga PAUD.

Orang tua adalah komponen keluarga yang terdiri dari ayah dan ibu dan merupakan hasil dari sebuah ikatan perkawinan yang sah yang dapat membentuk sebuah keluarga. Menurut Nasution (1986, p.1) orang tua adalah orang yang bertanggung jawab dalam satu keluarga atau tugas rumah tangga yang dalam kehidupan sehari-hari disebut Bapak dan Ibu, sehingga orang tua memiliki tanggung jawab untuk mendidik, mengasuh dan membimbing anak-anaknya untuk mencapai tahapan tertentu yang menghantarkan anak untuk siap dalam kehidupan bermasyarakat. Orang tua yang baik adalah orang tua yang mengungkapkan cinta dan kasih sayang, mendengarkan anak, membantu anak merasa aman, mengajarkan aturan dan batasan, memuji anak, menghindari kritikan dengan berfokus pada perilaku, selalu konsisten, berperan sebagai model, meluangkan waktu untuk anak dan memberi pemahaman spiritual.

Karena orang tua sebagai pelaksana pendidikan anak usia dini dalam keluarga maka peran orang tua sebagai pengemban tanggung jawab pendidikan anak usia dini. Ahmad (2008, p.81) menyebutkan bahwa peran orang tua adalah peran ibu dan peran ayah.

Sesuai dengan fungsi serta tanggung jawabnya sebagai anggota keluarga dapat di simpulkan bahwa peranan ibu dalam pendidikan anak-anaknya adalah sebagai sumber dan pemberi rasa kasih sayang, pengasuh dan pemelihara, tempat mencurahkan isi hati, pengatur kehidupan dalam rumah tangga, pembimbing hubungan pribadi, pendidik dalam segi-segi emosional.

Seorang Ayah memegang peranan penting disamping Ibu. Anak memandang ayahnya sebagai seorang yang tertinggi gengsinya atau prestisenya. Kegiatan seorang ayah terhadap pekerjaannya sehari-hari sungguh besar pengaruhnya kepada anakanaknya, lebih-lebih anak yang telah agak besar. Tugas dan tanggung jawab ayah dan ibu di dalam keluarga, ditinjau dari fungsi dan tugasnya sebagai ayah, dapat di kemukakan di sini bahwa peranan ayah dalam pendidikan anak-anaknya yang lebih dominan adalah sebagai sumber kekuasaan dalam keluarga, penghubung Intern keluarga dengan masyarakat atau dunia luar, pemberi perasaan aman bagi seluruh anggota keluarga, pelindung terhadap ancaman dari luar, hakim atau yang mengadili jika terjadi perselisihan, pendidik dalam segi-segi rasional.

Sedangkan pengertian orang tua tadi tidak terlepas dari pengertian keluarga, karena orang tua merupakan bagian keluarga besar yang sebagian besar telah tergantikan oleh keluarga inti yang terdiri dari ayah, ibu dan anak-anaknya. Hal ini sesuai dengan pendapat Arifin dalam (Suhendi, Wahyu, 2000, p.4) keluarga diartikan sebagai suatu kelompok yang terdiri dari dua orang atau lebih yang dihubungkan dengan pertalian darah, perkawinan atau adopsi (hukum) yang memiliki tempat tinggal bersama. Rochamah (1996, p.1) juga berpendapat bahwa keluarga adalah satuan terkecil dari persekutuan hidup manusia yang terdiri dari ayah, ibu serta anak-anaknya yang bersamasama hidup pada suatu tempat tinggal membentuk kelompok yang sifatnya primer dan relatif langgeng.

Keluarga merupakan kelompok orangorang yang dipersatukan oleh ikatan perkawinan, darah atau adopsi yang mem- 
bentuk satu rumah tangga yang berinteraksi dan berkomunikasi satu sama lain dengan melalui peran-perannya sendiri sebagai anggota kelompok dan yang mempertahankan kebudayaan masyarakat yang berlaku umum atau menciptakan kebudayaan sendiri.

Vembrianto (1993, p.33) mengatakan bahwa intisari pengertian keluarga adalah : (a) Merupakan kelompok sosial terkecil yang umumnya terdiri dari ayah, ibu dan anak. (b) Hubungan sosial diantara anggota keluarga relatif tetap didasarkan atas ikatan darah, perkawinana atu adopsi. (c) Hubungan antar ikatan anggota keluarga dijiwai suasan afeksi dan rasa tanggung jawab. (d) Fungsi keluarga adalah memelihara, merawat dan melindungi anak dalam rangka sosialisasi, agar mereka mampu mengendalikan diri dan berjiwa sosial.

Keluarga merupakan unit sosial terkecil yang memberikan pondasi primer bagi perkembangan anak, karena itu baik buruknya struktur keluarga memberikan pengaruh bagi pertumbuhan kepribadian anak. Keluarga merupakan lembaga pendidikan yang pertama dan utama, karena dalam keluarga manusia dilahirkan berkembang menjadi dewasa. Bentuk dan isi serta caracara pendidikan di dalam keluarga akan selalu mempengaruhi tumbuh dan berkembangnya watak, budi pekerti dan kepribadian tiap-tiap manusia. Sehingga pendidikan yang paling banyak diterima anak adalah didalam keluarga.

Keluarga sebagai sebuah sistem sosial mempunyai tugas atau fungsi agar sistem tersebut berjalan. Agar fungsi keluarga berada pada kondisi optimal, perlu peningkatan fungsionalisasi dan struktur yang jelas, yaitu suatu rangkaian peran dimana sistem sosial dibangun. Keluarga berfungsi untuk mengelola sumberdaya yang dimiliki (fungsi ekonomi) melalui prokreasi, sosialisasi (termasuk penetapan peran sosial), dukungan dan perkembangan anggota keluarga untuk memenuhi kebutuhan fisik, emosi (cinta kasih, ikatan suami-istri), perkembangan, moral (agama), loyalitas dan sosialisasi.

Peran keluarga yang berhubungan dengan fungsi cinta kasih juga sangat ber- peranan dalam memberikan lingkungan psikologi yang sehat bagi semua anggota keluarga untuk tumbuh berkembang mencapai potensi optimum. Keluarga sebagai institusi utama dalam pengembangan SDM juga berkaitan dengan fungsi sosialisasi. Sosialisasi merupakan proses dimana individu mendapatkan pengetahuan, keterampilan, dan karakter yang memungkinkannya berpartisipasi sebagai anggota kelompok atau masyarakat yang efektif, oleh

Karenanya berlangsung seumur hidup. Sosialisasi memungkinkan anak mengembangkan potensi dan membentuk hubungan kepuasan melalui pengembangan konsep diri, penanaman konsep disiplin, penanaman ambisi, pengajaran peran sosial dan pengajaran ketrampilan. Melalui sosialisasi, anak akan memasuki sistem sosial sebagai orang dewasa, dan akan memperoleh berbagai pelajaran dan latihan untuk mengenal norma-norma yang berlaku dalam masyarakatnya, sehingga mampu melakukan berbagai peran sosial yang diharapkan, menurut kualitas yang diantisipasikan oleh lingkungan atau masyarakat sekitarnya.

Dari pendapat di atas pada prinsipnya orang tua bertanggung jawab untuk memelihara, mendidik dan melindungi anak. Suasana hubungan di dalam keluarga memberi corak bagi perkembangan anak usia dini. Keluarga yang hangat memberikan kestabilan jiwa pada seorang anak, kematangan dalam emosi dan kesukaan dalam belajar. Mengingat pentingnya pendidikan anak usia dini, peran orang tua dalam menumbuhkan kembangkan anak sangat diperlukan. Dorongan atau motivasi dari orang tua akan membuat anak bertumbuh dan berkembang dengan baik. Orang tua diharapkan dapat mengembangkan seluruh potensi yang dimiliki anak seperti berpikir, berkomunikasi, berkreasi, sains, olah raga dan sebagainya sehingga potensi-potensi tersebut dapat berkembang secara optimal, sehingga anak tumbuh menjadi anak yang mandiri, sehat dan cerdas.

Setiap Orang tua mengharapkan anaknya patuh dan banyak lagi harapan lain tentang anak yang kesemuanya berbentuk sesuatu yang positif. Sementara itu setiap orangtua Berkeinginan untuk mendidik 
anaknya secara baik dan berhasil. Mereka berharap mampu membentuk anak yang punya kepribadian,anak yang beriman, bertaqwa kepada Tuhan Yang Maha Esa, anak yang berakhlak mulia, anak yang berbakti terhadap orangtua,anak yang berguna bagi dirinya, keluarga, masyarakat, nusa, bangsa, negara juga bagi agamanya.

Peran Pendidik di dalam UU nomor 20 pasal 39 ayat 2 menjabarkan bahwa pendidik adalah tenaga profesional yang bertugas merencanakan dan melaksanakan proses pembelajaran, menilai hasil pembelajaran, melakukan pembimbingan dan pelatihan, serta melakukan penelitian dan pengabdian kepada masyarakat, terutama bagi pendidik pada perguruan tinggi.

Dari pengertian di atas dijelaskan bahwa tenaga pendidik tidak hanya guru, melainkan semua pihak yang terlibat dalam penyelenggaraan pendidikan. Namun untuk dapat dikatakan sebagai pendidik haruslah mampu merencanakan, melaksanakan, menilai, melakukan pembimbingan dan pelatihan dalam pembelajaran. Jika merujuk pada penelitian ini yang dikatakan pendidik PAUD adalah orang yang bertanggung jawab merencanakan, melaksanakan, menilai, melakukan pembimbingan dan pelatihan dalam pembelajaran pada anak usia 2-6 tahun secara menyeluruh.

Sekolah merupakan lembaga pendidikan yang kedua setelah pendidikan keluarga. Maka dari itu sekolah mempunyai peranan penting untuk meneruskan dasardasar pendidikan keluarga. Pada umumnya sekolah merupakan tempat anak didik untuk memperoleh pengalaman-pengalaman, pengetahuan, keterampilan sehingga anak didik akan mendapat bekal hidup kelak bekerja di lingkungan masyarakat luas. Pendidik adalah guru dengan tugas utama mendidik, mengajar, membimbing, mengarahkan, melatih, menilai, sehingga perannya sangat penting supaya peserta didik nantinya memiliki kemampuan kognisi, afeksi dan psikomotorik.

Dalam pengembangan sikap disiplin, pendidik mempunyai tanggung jawab membimbing anak didiknya agar memiliki pemahaman tentang peraturan dan norma-norma dan dapat berperilaku sesuai dengan peraturan dan norma-norma tersebut.

Secara umum Kusriyati dan Desminarti (1990, p.1) menyatakan perilaku manusia pada hakekatnya adalah proses interaksi individu dengan lingkungannya sebagai manifestasi hayati bahwa dia adalah makhluk hidup.

Kemudian dapat disimpulkan bahwa perilaku adalah tindakan manusia yang dapat diamati yang merupakan alternatif tindakan atas beberapa pilihan. Tindakan terjadi setelah manusia menentukan sikap. Jadi perilaku adalah buah dari sikap seseorang. Skinner (Sarwono, 1984, p.84) membedakan perilaku menjadi, perilaku alami yaitu perilaku yang dibawa sejak organisme dilahirkan, yaitu berupa reflek-reflek dan insting-insting dan perilaku operan (operan behaviour) yaitu perilaku yang dibentuk melalui proses belajar. Sedangkan yang dimaksud perilaku dalam penelitian ini adalah tindakan manusia yang dapat diamati yang merupakan alternatif tindakan atas beberapa pilihan yang dibentuk melalui proses belajar.

Beberapa cara yang bisa dipakai untuk pembentukan perilaku yaitu dengan cara pembentukan perilaku berdasarkan kondisioning atau kebiasaan. Misal, membiasakan diri menggosok gigi sebelum tidur malam hari. Pembentukan perilaku yang lain adalah ditempuh dengan cara pengertian. Contoh, anak usia dini dibiasakan menggosok gigi sebelum tidur malam hari karena kalau tidak melakukannya bisa sakit gigi. Cara lain lagi yaitu dengan menggunakan model, sebagai acuan dalam pembentukan perilaku yang diharuskan.

Menurut Kenneth \& Laurie (2005, p.12) kata disiplin yang dalam bahasa inggris discipline, berasal dari akar kata bahasa latin yang sama (discipulus) dengan kata "disciple" dan mempunyai makna yakni seorang yang belajar dari atau secara sukarela mengikuti seorang pemimpin yang dihormati. Orang tua dan pendidik merupakan pemimpin dan anak merupakan murid yang belajar dari mereka cara hidup yang berguna dan bahagia. Disiplin disini dimaksudkan sebagai cara kita mengajarkan perilaku moral yang dapat diterima oleh masyarakat terutama di lingkungan keluarga dan lembaga pendidikan. 
Dari pengertian tersebut dapat disimpulkan bahwa disiplin adalah tata tertib atau peraturan yang harus dilakukan dalam kehidupan sehari-hari untuk melatih watak anggota yang ada dalam lermbaga pendidikan.

Disiplin berkaitan dengan motivasi, karena dengan adanya disiplin anak terdorong melakukan perbuatan-perbuatan tertentu untuk mencapai apa yang diharapkan orang lain darinya, apakah itu keluarga, orang tua, guru maupun teman-temanya. Pada awalnya disiplin dirasakan sebagai suatu aturan yang mengekang kebebasan anak. Akan tetapi bila aturan tersebut dirasakan sebagai suatu yang memang seharusnya dipatuhi secara sadar untuk kebahagiaan diri anak dan kebaikan bersama, maka lama kelamaan akan menjadi suatu kebiasaan yang baik menuju kearah disiplin diri sendiri (self discipline), artinya disiplin tidak lagi merupakan suatu yang datang dari luar dirinya yang memberikan keterbatasan tertentu. Dalam hal ini disiplin telah merupakan suatu aturan yang datang dari dalam diri sebagai suatu aturan tentang suatu hal yang wajar dialkukan anak dalam kehidupan sehari-hari. Menurut padangan psikologi, anak usia dini biasanya memiliki karakteristik yang khas dan berbeda dengan anak yang lain yang berada diatas usia 8 tahun. Kelloguh (1966, pp.45-46) menyebutkan bahwa karakteristik tersebut adalah (1) Anak usia dini itu bersifat egosentris, (2) Anak memiliki rasa ingin tahu yang besar, (3) Anak adalah mahluk sosial, (4) Anak bersifat unik, (5) Anak umumnya kaya fantasi, (6) Anak memiliki dasar konsentrasi yang pendek, (7) Anak merupakan masa belajar yang potensial.

\section{METODE}

Penelitian ini merupakan penelitian kuantitatif dengan pengertian yaitu penelitian yang tersusun secara sistematis antara bagain-bagian, fenomena serta hubunganhubungan yang terdapat dalam objek penelitian. Tujuan penelitian kuantitatif adalah agar dapat mengembangkan dengan menggunakan model yang matematis dengan teori-teori atau adanya hipotesis yang berkaitan dengan suatu kejadian atau feno- mena yang terjadi. Oleh sebab itu dalam melakukan penelitian kuantitatif perlu adanya hubungan antara pengamatan secara empiris. Maksud secara empiris adalah menggunakan subyek yang nyata sehingga peneliti dapat menggali data melalui suatu daftar pertanyaan atau kuesioner terhadap partisipan atau responden. Caranya dengan riset ke lapangan/observasi dari ekspresi matematis dari hubungan-hubungan kuantitatif.

Menurut Creswell (2009, pp.27-28) Penelitian kuantitatif menguji suatu teori dengan cara memerinci hipotesis-hipotesis yang spesifik, lalu mengumpulkan data-data untuk mendukung atau membantah hipotesis-hipotesis tersebut. Strategi eksperimen diterapkan untuk menilai perilaku-perilaku, baik sebelum dan sesudah proses eksperimen. Data-data dikumpulkan dengan bantuan istrumen khusus yang dirancang untuk menilai perilaku-perilaku sedangkan informasi-informasi dianalisis dengan menggunakan prosedur-prosedur statistik dan pengujian hipotesis.

Pada umumnya di berbagai bidang ilmu dan kehidupan untuk mengetahui/ memahami sesuatu diperlukan data. Statistika mempelajari tentang bagaimana mengambil data, mengolah data, mendeskripsikannya, dan menganalisanya untuk mendapatkan kesimpulan. Menurut Sudjana (2005, p.2) Statistik dipakai untuk menyatakan ukuran sebagai wakil kumpulan data mengenai sesuatu hal. Dalam melakukan penelitian kuantitatif diperlukan data statistik melalui penghitungan ilmiah yang dihasilkan atau didapat dari populasi, sampel dan dilakukan pengujian terhadap normalisasi data. Sedangkan statistik dengan pengertian sebagai data kuantitatif atau data statistik adalah data angka yang dapat memberikan gambaran mengenai keadaan, peristiwa atau gejala yang sedang berlangsung (Sudijono, 2008, p.3). Statistik berfungsi juga sebagai alatbantu untuk mengolah, menganalisis dan menyimpulkan hasil yang akan dicapai dalam kegiatan penelitian ini.

Peneliti ingin mengungkapkan hubungan antar variabel yang hasil analisisnya disajikan dalam bentuk deskriptif dengan 
menggunakan angka-angka statistik yang dipakai untuk menyatakan kumpulan data, bilangan maupun non-bilangan yang disusun dalam tabel atau diagaram yang menggambarkan suatu persoalan. Sehingga metode penelitian yang akan digunakan untuk mengungkap hubungan peran orang tua dan pendidik dalam menerapkan perilaku disiplin terhadap anak usia dini adalah metode penelitian kuantitatif deskriptif. Lokasi Penelitian di Kelompok Bermain Surya Marta yang berdomisili di jalan Suryodiningratan nomor 43 Kelurahan Suryodiningratan Kecamatan Mantrijeron Yogyakarta. Waktu penelitian pada bulan Maret sampai Mei 2013. Populasi penelitian adalah siswa/siswi kelompok bermain Surya Marta yang berjumlah 35 anak dengan rentang usia 2 tahun sampai 5 tahun.

Ada tiga variabel yang digunakan dalam penelitian ini adalah variabel peran orang $\left(\mathrm{X}_{1}\right)$, variabel peran pendidik $\left(\mathrm{X}_{2}\right)$ dan variabel perilaku disiplin (Y). Pada penelitian ini yang dimaksud definisi operasional variabel peran orang tua adalah proses bantuan yang tersedia terus-menerus dari orang tua kepada anak usia dini agar tercapai pemahaman diri, pengarahan diri dan perwujudan diri dalam berperilaku disiplin. Demikian juga variabel peran pendidik adalah proses bantuan yang tersedia terus-menerus dari pendidik kepada anak usia dini agar tercapai pemahaman diri, pengarahan diri dan perwujudan diri dalam berperilaku disiplin. Sedangkan variabel perilaku disiplin adalah perilaku anak usia dini dalam membuat pilihan-pilihan lebih baik, bertanggung jawab, berfikir sendiri, serta mempunyai kemampuan untuk memilih cara mereka sendiri.

Teknik pengumpulan data yang digunakan adalah (1) Wawancara melalui komunikasi langsung(tatap muka) antara pihak penanya dengan pihak ditanya. Dalam penelitian ini digunakan wawancara terstruktur dengan menggunakan daftar pertanyaan tertulis dan jawabannya sudah disediakan yang berbentuk skala. Pewawancara membacakan pertanyaan yang ada dalam pedoman tersebut dan menanyakan kepada responden (anak) tentang jawabannya sesuai dengan pernyataan dalam skala yang telah disiapkan. Instrumen penelitian yan digunakan untuk mengumpulkan data melalui wawancara terstruktur pada anak usia dini tentang peran orang tua dan pendidik dalam menerapkan perilaku disiplin. (2) Observasi dengan melakukan pengamatan secara langsung ke objek penelitian untuk, melihat dari dekat kegiatan yang dilakukan. Dalam penelitian ini untuk mendukung data hasil wawancara dari anak usia dini maka observasi yang dilakukan yaitu observasi tidak terstruktur supaya peneliti dapat melakukan pengamatan bebas, mencatat apa yang terjadi, melakukan analisa dan kemudian membuat kesimpulan.

Tolok ukur penyusunan instrumen penelitian adalah varaibel-variabel penelitian yang ditetapkan untuk diteliti. Dari variabel-variabel penelitian yang ditetapkan untuk diteliti dijabarkan menjadi bagianbagian yang lebih kecil yang disebut indikator. Indikator inilah yang menjadi deskriptor, yaitu elemen-elemen yang akan ditulis dalam kuesioner untuk dicari datanya. Dari indikator yang akan diukur kemudian dijabarkan menjadi butir-butir pertanyaan. Penyusunan instrumen penelitian bertitik tolak dari variabel-variabel yang akan diteliti.

Pengembangan instrumen yang dimaksud adalah untuk mengungkap perilaku disiplin anak usia dini yang nampak pada siswa/i di Kelompok Bermain Surya Marta. Untuk mengumpulkan data tentang perila$\mathrm{ku}$ disiplin anak usia dini, peran orang tua dan peran pendidik dapat disusun butirbutir pertanyaan yang dikembangkan dari indikator dalam instrumen penelitian.

Validitas bertujuan untuk melihat tingkat keabsahan atau ketetapan suatu alat ukur. Suatu instrumen dikatakan valid jika dapat mengukur apa yang sebenarnya diukur. Pengujian validitas dilakukan dengan analisis faktor yaitu mengkorelasikan antar skor butir soal dengan skor total dengan menggunakan rumus Pearson Product Moment.

Reliabilitas bertujuan untuk menunjukkan sejauh mana suatu hasil pengukuran relatif konsisten dalam mengungkapkan gejala tertentu dari suatu individu, walaupun dilakukan pada waktu yang berbeda. 
Penelitian ini merupakan penelitian kuantitatif dengan menggunakan pendekatan deskriptif yang bertujuan untuk melihat pengaruh yang sedang berlangsung saat ini dan data yang dikumpulkan bersifat kuantitatif. Teknik pengolahan data yang digunakan adalah teknik korelatif untuk melihat hubungan antara berbagai variabel. Secara garis besar langkah-langkah pengolahan data yang dilakukan sebagai berikut (1) Menyeleksi data agar dapat diolah lebih lanjut dengan cara memeriksa hasil instrumen penelitian sesuai kriteria yang telah ditetapkan. Kemudiandilakukan penghitungan untuk setiap item variabel penelitian dengan cara menjumlahkan berbagai alternatif jawaban dari masing-masing responden sesuai dengan bobot skala penelitian yang telah ditentukan kemudian menentukan skor, (2) Data variabel penelitian yang dianalisis dengan menggunakan analisis teknik korelasi harus memenuhi persyaratan uji analisis yang digunakan. Analisis korelasi mensyaratkan data harus berdistribusi normal dan linier, untuk itu perlu di uji normalitas dan linieritas, 3. Teknik korelasi untuk mengetahui pengaruh variabel $\mathrm{X}_{1}$ terhadap Y, X2 terhadap Y, 4. Menggunakan rumus korelasi ganda untuk mengetahui pengaruh antara veraibel $\mathrm{X}_{1}$ dan $\mathrm{X}_{2}$ secara bersama-sama terhadap Y.

\section{HASIL DAN PEMBAHASAN}

Hasil penelitian menunjukkan bahwa pada variabel peran orang tua didapat nilai korelasi sebesar -0,025. Hal ini menunjukan bahwa tingkat keeratan hubungan antara variabel peran orang tua terhadap perilaku disiplin anak sangat lemah, dan tanda korelasi negative menunjukan adanya hubungan terbalik antara kedua variabel, yaitu jika peran orang tua meningkat maka akan terjadi penurunan terhadap perilaku disiplin anak, begitupun sebaliknya. Bisa dikatakan salah satu penyebab beberapa orang tua belum menerapkan perilaku disiplin bagi anaknya karena orang tua bekerja sehingga pengasuhan diserahkan kepada keluarga yang lain bahkan orang lain seperti tetangga, pembantu, baby sitter seperti yang terjadi di kelompok bermain surya marta. Orang tua merasa anaknya tidak menurut contoh penerapan perilaku disiplin karena anak mendapatkan contoh penerapan perilaku disiplin dari orang yang mengasuh.

Pada variabel peran pendidik nilai korelasi yang didapatkan sebesar 0,270. Hal ini menunjukan bahwa tingkat keeratan hubungan antara variabel Peran pendidik terhadap Perilaku Disiplin Anak adalah lemah, dan tanda korelasi positif menunjukan adanya hubungan searah antara kedua variabel, yaitu Jika Peran Pendidik meningkat maka akan terjadi peningkatan terhadap Perilaku Disiplin anak usia dini, begitupun sebaliknya. Meskipun keeratan hubungan antara variabel peran pendidik yang nampak dalam kategori lemah, namun nilai positif menunjukkan hubungan yang searah karena peran pendidik dalam menerapkan perilaku disiplin anak usia dini secara berulang-ulang dan terus menerus.

Pada variabel peran orang tua dan pendidik secara bersama-sama nilai Korelasi yang didapatkan yaitu o,313. Hal ini menunjukan tingkat keeratan antara variabel Peran Orang Tua dan Pendidik secara bersamasama berpengaruh terhadap perilaku disiplin anak usia dini masuk dalam kriteria lemah, dan tanda korelasi positif menunjukkan adanya hubungan searah antara variabel yaitu jika peran orang tua dan pendidik secara bersama-sama meningkat maka akan terjadi peningkatan terhadap perilaku disiplin anak usia, begitupun sebaliknya. Peran orang tua dan pendidik secara bersama-sama berpengaruh masih dalam kriteria lemah berarti peran orang tua dan peran pendidik yang nampak belum selaras bisa dikatakan penerapan disiplin yang dilakukan oleh pendidik berbeda dengan orang tua. Orang tua masih beranggapan belum waktunya menerapkan disiplin terhadap anak usia dini sebagai contoh pada penerapan disiplin menggosok gigi sebelum tidur banyak orang tua mengatakan anaknya seringkali langsung tertidur karena lelah bermain, belum dibiasakan bangun di pagi hari karena merasa kasihan pada anak yang masih kecil.

Kemudian Masa usia dini anak yaitu o sampai 6 tahun merupakan masa emas (golden age ) dimana pada masa ini perkembangan otak anak mencapai 50\% hingga usia 6 tahun mencapai 8o\% sehingga merupakan 
masa yang terpenting dan hanya satu kali terjadi dalam perkembangan kehidupan manusia. Pada masa usia 2- 7 tahun anak masuk dalam tahap perkembangan pra-operasional, sudah banyak memperoleh pengaruh lingkungan. Panca inderanya berada pada masa peka, itulah sebabnya anak menggunakan panca inderanya dalam mengeksplorasi dunia luar. Perkembangan psikis yang menonjol terlihat membangkang dan menentang orang tua. Anak melanggar apa yang dilarang sebaliknya anak menolak apa yang seharusnya dilakukan. Masa perkembangan ini merupakan masa yang sulit bagi orang tua maka perlakuan orang tua harus bijaksana. Anak adalah individu yang unik, yang berbeda antara satu dengan yang lain. Hal ini semestinya dipahami agar tidak menyamaratakan perlakuan terhadap anak karena akan memberikan dampak yang tidak baik. Perkembangan masa ini sudah banyak dipengaruhi oleh faktor lingkungan. Anak mulai mengenal dan menemukan lingkungannya, perkembangan terjadi diseputar penguasaan dan pengetahuan lingkungan.

\section{PENUTUP}

\section{Simpulan}

Hasil penelitian tentang Peran Orang Tua dan Pendidik dalam menerapkan Perilaku Disiplin terhadap Anak Usia Dini .yang telah dilakukan menyimpulkan bahwa (1) Tingkat keeratan hubungan antara peran orang tua dan pendidik secara bersamasama dengan perilaku disiplin anak usia dini masuk dalam kriteria lemah dan hubungannya tidak searah antar kedua variabel yaitu jika peran orang tua dan pendidik secara bersama-sama meningkat maka akan terjadi penurunan perilaku disiplin anak usia dini, begitupun sebaliknya. Sehingga ada pengaruh peran orang tua dan pendidik dalam menerapkan perilaku disiplin terhadap anak usia dini, dengan demikian hipotesisı terbukti, (2) Tingkat keeratan hubungan antara peran orang tua dengan perilaku disiplin anak usia dini masuk dalam kriteria sangat lemah dan hubungannya berbanding terbalik antar kedua variabel yaitu jika peran orang tua meningkat maka akan terjadi penurunan perilaku disiplin anak usia dini, begitupun sebaliknya. Sehingga hal ini membuktikan ada pengaruh peran orang tua dalam menerapkan perilaku disiplin terhadap anak usia dini, dengan demikian hipotesis 2 terbukti, (3) Tingkat keeratan hubungan antara peran pendidik dengan perilaku disiplin anak usia dini masuk dalam kriteria lemah dan hubungannya searah antara kedua variabel yaitu jika peran pendidik meningkat maka akan terjadi peningkatan perilaku disiplin anak usia dini, begitupun sebaliknya. Sehingga hal ini membuktikan ada pengaruh peran pendidik dalam menerapkan perilaku disiplin terhadap anak usia dini, dengan demikian hipotesis 3 terbukti.

\section{Saran}

Berdasarkan simpulan tersebut maka peneliti menyarankan beberapa hal sebagai berikut Pertama peran orang tua dan pendidik dalam menerapkan perilaku disiplin terha-dap anak usia dini yang nampak di Kelom-pok Bermain Surya Marta adalah lemah. Peneliti menyarankan perlunya ada kerja sama antara orang tua dan pendidik dalam menerapkan perilaku disiplin, mengingat keselarasan pembiasaan disiplin harus terus menerus dan berulang-ulang diterapkan di rumah maupun di sekolah. Komunikasi rumah-sekolah juga memainkan satu peran kunci dalam keterlibatan orang tua pada program sekolah. Hubungan yang dekat dan komunikasi reguler antara rumahsekolah sebagai awal pengembangan pendidikan anak usia dini. Menurut penelitian yang dilakukan oleh Bridgemohan, Van Wyk dan Van Staden "Komunikasi RumahSekolah Dalam Tahap Awal Pengembangan Masa Kanak-Kanak" menyimpulkan bahwa komunikasi yang baik antara rumah-sekolah adalah hal yang sangat penting untuk membina hubungan rumah-sekolah. Para orang tua bisa menghendaki keterlibatannya untuk menjadi bagian dari komunikasi sekolah. Program pendidikan anak usia dini sangat erat hubungannya dengan komunikasi yang terjalin terus-menerus antar rumah-sekolah dalam memperbaiki konsistensi tujuan bersama antara orang tua dan pendidik dalam pengembangan anak didik. 
Kedua, peran orang tua dalam menerapkan perilaku disiplin terhadap anak usia dini yang nampak pada Kelompok Bermain Surya Marta masuk dalam kategori sangat lemah, hal ini bisa disebabkan sebagian besar orang tua belum mengetahui pentingnya program parenting, terbukti pada saat penyelenggaraan program parenting yang telah dilaksanakan satu tahun dua kali sebagian besar orang tua tidak hadir, bahkan yang hadir orang terdekat atau keluarga yang mengasuh anak (Pada program parenting yang diselenggarakan pada Semester 2 tahun pelajaran 2012-2013 orang tua yang hadir 17 orang dari jumlah siswa/i 42 anak). Dalam hal ini peneliti memberikan saran kepada pihak Sekolah untuk lebih mensosialisasikan pentingnya program parenting, materi yang dibahas berkesinambungan dan waktu penyelenggaraan ditambah, 3 .

Ketiga, peran pendidik dalam menerapkan perilaku disiplin terhadap anak usia usia dini yang nampak di Kelompok Bermain Surya Marta masuk dalam kategori lemah. Keadaan ini bisa terjadi karena jika dilihat pada data pendidik, semua pendidik tidak mempunyai latar belakang pendidikan anak usia dini, tetapi semua pendidik bersertifikat latihan pendidikan anak usia dini dan berpengalaman mengajar di sekolah minggu Gereja. Sehingga peneliti menyarankan sebaiknya setiap pendidik PAUD harus mempunyai latar belakang pendidikan anak usia dini. Sehingga adanya model yang bermutu untuk ditiru anak baik di rumah dan di sekolah akan memberikan konsistensi model yang ditiru. Karena anak usia dini sebagian waktunya dihabiskan di dalam keluarga baru di sekolah. Komunikasi anak dengan orang tua, dengan orang lain yang tinggal serumah, dengan tetangga dan guru di sekolah bagi anak akan terlihat seperti film yang selalu diputar setiap hari dengan episode yang bermacam-macam dan mengendap dalam Ingatan Jangka Panjang (IJP) anak atau Longterm Memory. Materi-materi yang ada tersimpan dalam IJP, ini kelak akan dikeluarkan lagi oleh anak bila diperlukan, saat anak berebut mainan, melepas sepatu di sekolah, berdoa akan mulai makan di sekolah, saat membuang sampah dsb, mereka akan "memanggil" (retrieve) lagi referensi yang telah tersimpan di dalam IJP. Jadi IJP adalah semacam gudang koleksi perilaku yang didapatnya sejak lahir hasil observasi dan peniruannya. Bisa dibayangkan bagaimana respon anak bila materi-materi yang selalu disimpannya adalah perilaku yang kasar, tidak sopan, bohong, kotor dsb. Bandingkan dengan materi yang disimpan dalam IJP adalah perilaku yang mandiri, disiplin, bersih, sopan, jujur.

\section{DAFTAR PUSTAKA}

Direktorat Pendidikan Anak Usia Dini, Ditjen Pendidikan Luar Sekolah dan Pemuda. Departemen Pendidikan Nasional. (2002). Acuan menu pembelajaran pada pendidikan anak usia dini (Menu Pembelajaran Generetik).

Direktorat Pendidikan Anak Usia Dini. Ditjen Pendidikan Luar Sekolah Departemen Pendidikan Nasional. (2004). Sosialisasi pendidikan anak usia dini.

Direktorat Pendidikan Anak Usia Dini, Ditjen Pendidikan Luar Sekolah. Departemen Pendidikan Nasional. (2006). Teknik penyelenggaraan kelompok bermain.

Kenneth.W.Requena, Ed.D \& Laurie Miller, Ed.D (2008). Good kids bad behaviour. Cet.I. Jakarta: Prestasi Pustakarya.

Materi Matrikulasi Program Pascasarjana UNY Yogyakarta (2011). Statistika. Yogyakarta.

Bridgemohan, Radhike., Van Wyk, Nollen., Van Staden, Christie (1992). Komunikasi rumah - sekolah dalam tahap awal perkembangan masa kanak-kanak. School of Education, University of South Africa.

Ruth K. Chao. ((1996). Chinese and european american mother's beliefs about the role of parenting in children's school success. Journal of Cross Cultural Psychology.Syracuse University.

Sitompul, S. \& Gultom, A. (2007). Pembelajaran pendidikan agama Kristen 
pada anak usia dini. Cet. I. Bandung: Bina Media Informasi.

Sudijono, A. (2008). Pengantar statistika pendidikan. Cet. I. Jakarta: PT Raja Grafindo Perkasa.

Sudjana, N. (2007). Penelitian dan penilaian pendidikan. Jakarta: Sinar Baru Algensondo.

Syaiful, B.D. (2005). Guru dan anak didik dalam interaksi edukatif. Cet.II. Jakarta: Rineka Cipta. von der Lippe, Anna Louis. (1999). The impact of maternal schooling and occupation on child-rearing attitudes and behaviours in low income neighbourhoods in Cairo, Egypt. International Journal of Behavioral Development.University of Oslo, Norway.

Wimbarti, S. (1997).Child-rearings of practise and temperaments of children: are they really determinants of children's aggresion? Psikologika 2, 5-18. 